\title{
EXTENDING OUR VISION OF DEVELOPMENTAL GROWTH AND ENGAGING IN EMPIRICAL SCRUTINY: PROPOSALS FOR THE FUTURE OF FAITH DEVELOPMENT THEORY
}

\author{
Heinz Streib \\ Research Center for Biographical Studies in Contemporary Religion, \\ University of Bielefeld
}

\begin{abstract}
This article evaluates the portrait of faith development theory and research in James Fowler's article, "Faith Development at 30." Questions are raised: Does Fowler's emphasis on the practical-theological and pastoral focus of faith development contradict its aspiration and disposition for empirical scrutiny? Does Fowler's principal concern with the reactions from Christian theologians and religious educators indicate disregard of and from psychology? Both questions can be denied with reference to the large amount of research projects which use and apply the faith development perspective. The article suggests further engagement in theory discussion, methodological clarification and empirical research; it invites networking among researchers and indicates future research strategies. But also the practical-theological relevance of faith development theory, especially for religious education, are demonstrated with reference to recent research. The article concludes, in agreement with Fowler, with a proposal to notice the importance of the Conjunctive Faith style for social bodies, and to include this in religious education. With the latter, the article moves beyond a wide-spread faith development application and argues against the false assumption as if children and adolescents could not understand and consider Conjunctive Faith.
\end{abstract}

It is an honor for me to be invited to respond to James Fowler's article in this journal issue. However, it is a challenge to keep my response brief, while commenting on at least some of the issues raised by this comprehensive narrative account of faith development's past and future. I shall highlight some new insights that the text offers or to which it draws fresh attention. I will expand on them and take them forward to proposals for the future of faith development theory that I regard as critical and decisive: empirical scrutiny and the enlargement of our vision of developmental growth. 
It is intriguing how biography and theory interrelate. This is my strong impression when reading such a detailed account of how the emerging theory of faith development is related to and rooted in the author's biography. Biographical lines converge and form a theme: Fowler's observation and his own experience of the dynamics of faith change as an adolescent may be as influential as his practical pastoral work in the Methodist Church. These experiences may have fueled his curiosity sufficiently to cause him to reflect on the dynamics of change in a person's faith and lead him to study theories and models that later became central for faith development theory-and again to become even more attentive to changes in people's life and faith. The powerful experiences in the Interpreter's House, to which Fowler has also referred previously, illuminate the origin and objective of faith development theory. It indicates a strong practical-theological, pastoral focus for the faith development perspective from the very beginning: The bottom line is, and has been, helping people reflect and grow in their faith through an hermeneutic process of communicative interpretation. This central practical target of the faith development perspective is worth considering when we reflect on its role and contribution in the new millennium. But if we want to emphasize this so decidedly, as Fowler does throughout his text, we should explicate that this entails a significantly broader perspective of what we normally expect from a theory and the related research. It involves care and attention rather than objectifying distance, intersubjective communication rather than objective evaluation and judgment. Does this mean that we feature pastoral and educational application at the cost of scientific empirical-methodological scrutiny? I don't think so. As I intend to make clear in the following, the practical-pastoral and educational application of faith development theory does not, and should not, impede its aspiration and disposition for empirical scrutiny. There may be a longer way to go before we arrive-hopefully better equipped with data and results - at the practical application.

As has been observed and noted frequently, theological contextualization has been Fowler's primary concern in the years after Stages of Faith was published. This is obvious from the books and articles that Fowler has published after 1981. Fowler's article confirms even more clearly that the reception and reaction on the part of theologians and religious educators in Christian churches and denominations has been a vital concern for Fowler. In contrast to this, we do not read much about the reactions from developmental or educational psychologists concerning theory construction and research methodology of faith 
development theory. It is my observation and conviction, however, that the times of friendly reserve toward the structural-developmental family of theories has come to an end: We see a rather thorough evaluation paired with sometimes harsh critique and decisive reconstruction in the fields of Piaget's theory of cognitive and Kohlberg's theory of moral development. This also has consequences for faith development theory. If, in the new millennium, faith development theory aspires to contribute to theory construction and research about the dynamics of faith, religion, and spirituality (as some recently suggest to rename the domain), ${ }^{1}$ there are complex tasks and challenges to be taken on. They concern theory discussion, methodological clarification, and empirical research. My own contribution is the religious styles perspective, which does not relinquish concern with stages, but focuses on a more complex concept of religious orientations ${ }^{2}$ and a broader variety of faith trajectories, including what I have called off-road religion (Streib, 1999). One of the urgent tasks of the faith development project, thus, consists of theoretical and methodological clarification and advancement. The faith development perspective still could gain more ground and claim its proper place in the human sciences, especially in psychology — as part of the theories and models for explaining personal change. Given the new interest in religion (or spirituality) in the human sciences, the chances are good for the faith development perspective-but only if it presents itself with conceptual and empirical scrutiny.

Certainly, Fowler's narrative not only accentuates the practicalpastoral roots of the emerging faith development perspective and its decisive theological profile, but his narrative also describes the beginnings and the progress of the extensive faith development research project with the 359 interviews on which Stages of Faith is based. In my evaluation of two decades of faith development research (Streib, 2003a), I have found no other single research project that has used the

${ }^{1}$ I still belong to the group of skeptics who doubt that we gain more conceptual clarity by simply renaming our field or adding "spirituality" to its designation. I propose instead that the concept of "religion" does indeed need conceptual clarification and adjustment to our contemporary religious landscape — and thereby include what many contemporaries are aiming at in their "spiritual quest." Because we have many valuable theories and models of religion that hold this potential and promise, it would be a step backward and a loss, if we left them aside.

${ }^{2}$ Drawing from psychoanalysis and more recent contributions to developmental psychology, I suggest a revision of faith development theory and research that could be called the religious styles perspective (see Streib, 2001a, 2003b, 2003c, 2004). 
classical faith development instrument ${ }^{3}$ with such a large number of interviews, even though over 30 research projects, if taken together, may add another 1,000 faith development interviews. This is an indication that the faith development project has become an extensive research network. Within the relatively short period of twenty years, faith development theory has spread out and inspired many research projects. If we count not only qualitative studies using the classical faith development instrument or a qualitative instrument variation, but also quantitative research, theory discussion, and application studies, we find over eighty dissertations with a primary focus on Fowler's faith development theory. More than half of these projects include empirical studies. The growing reputation of faith development theory had its seismic focus in Emory University's Center for Faith Development, but the Center in Atlanta did not claim to be the one and only faith development research laboratory with a rigid coordination of research or a sacrosanct theory and methodology. Rather, faith development theory, from the early years on, had a history of widespread dissemination and, therefore, of heavy critique, but also of creative evolution in theory and research method.

One of the consequences I draw from my evaluation of twenty years of faith development research is that we need more empirical projects. We must also invite researchers to network their research projects more coherently in the future. Among the desiderata are projects that focus on particular fields, such as religious education or pastoral care-paying particular attention to client assessment, but also to intervention effects. Of particular importance is cross-cultural research-to which we are about to contribute in our International Study of Deconversion. ${ }^{4}$ The most ambitious project would be longitudinal research — which would finally put the assumption of development to the test and yield insights into the circumstances under which we may expect developmental progress. Finally, even though I see the future of faith development research primarily in the qualification of the qualitative instrument- the inclusion of narrative approaches and

\footnotetext{
${ }^{3}$ The classical faith development instrument follows the questions and evaluation procedures of the Manual for Research in Faith Development that was published in its first edition in 1986 (Moseley, Jarvis, and Fowler, 1986) and was followed by a second edition (Moseley, Jarvis, and Fowler, 1993). We have prepared a third edition in Bielefeld (Fowler, Streib, and Keller, 2004).

${ }^{4}$ For details, see our website at: http://www.uni-bielefeld.de/theologie.ISD. We have published first results there and will announce results and publications there as they become available.
} 
the account for content dimensions hold the most promise-I also acknowledge the need for a good quantitative instrument. We would need considerable time and energy to revise the instruments that have been developed so far or invent new ones and put them on thorough testing for reliability and validity. ${ }^{5}$

Empirical scrutiny and the increase of solid research results are important steps, but we cannot stop there when keeping in mind the decisive practical-theological and pastoral focus of faith development theory. Particularly in the field of religious education, the faith development perspective should stand the test of practical relevance. The interest in the faith development perspective on the part of religious educators has been tremendous, as a statistic of the most valued books in religious education, compiled by Walter (1996), has revealed. These statistics brought to light that the books on Fowler's theory are the absolute bestsellers among religious educators in the United States. They have ranged three faith development books among the top four. In a meta-analysis of dissertations, considered as highly relevant to adult faith development, Vanlue (1996) has also identified sixty such dissertations completed between 1980 and 1994, among them twentysix dissertations with a primary focus on Fowler's work. This can be taken as another indication of the special recognition of Fowler's faith development theory in religious education in the United States. Religious education appears to be the key field for which Fowler's theory is regarded to provide new insights. The focus on religious education is obvious in both the United States and Europe-even if on a considerably lower level for Europe.

It is noteworthy that Fowler avoids the simplifications that narrow the aim of education to development (Kohlberg and Mayer 1972; Gmünder 1979). Rather-and Fowler's article is explicit about thishe highlights the "tremendous impact" of the "structuring power of the contents of faith" on faith formation, especially for children, and regards development in faith to be a "byproduct" and not a primary goal in religious education. It must be emphasized that this requires a great deal of patience on the part of the religious educator who, if trained in the faith development perspective to identify the faith stage of participants, should nevertheless provide a nurturing and stable environment. This is particularly difficult because some impatience is justified, and even necessary, in view of the challenges of the new

${ }^{5}$ The development of a quantitative instrument is in progress also as a by-product in the International Study of Deconversion. 
millennium, where we see a lack of faith and faith development in many societal, ethical, and inter-religious domains and, at the same time, an overload of problematic religion in fundamentalist niches.

One of the helpful new insights could derive from an advancement of faith development theory. If we depict faith development as more complex and permeable, the religious educators can also abandon the blinkers narrowing their perspective, currently causing them to act as if only one stage were available and understandable for their clients. Religious educators might reckon with and nurture an awareness and trial adoption of higher faith styles. I therefore appreciate Fowler's reference to conjunctive faith as a potential answer to the needs of our world today and tomorrow in the final passage of his article. Already in Faithful Change (Fowler 1996), he has made the case that the Conjunctive Faith Stage's parallel, in what he calls a postmodern societal structure, shows a way beyond the culture war and tension between the orthodox and the progressive models of society. This analysis of society leads primarily to the proposal "to claim and model Conjunctive faith in American society," but this analysis also leads Fowler to inquire what theology has to offer as response to postmodern challenges. What is hinted at only between the lines here, but should be regarded as a major advancement of faith development theory, is its application as a means of understanding social bodies and social conflicts and to suggest a promising answer to the predicaments of modernity. This potential for faith development theory to provide a model for understanding social differentiation and conflict in society and religious communities should not be underestimated, but should be elaborated. I suggest to explicate this also for religious education.

This would imply that we include and refer to instances and examples of Conjunctive Faith in religious education, and that we do not hesitate to explain this as an offer and option even for the young. This in turn has theoretical implications: Is the dialog and the appreciation of the strange other an option even for children and adolescents? If we answer yes to this question-which is what I suggest—-then the stages of faith are not confined to a certain age; there is more permeability and flexibility. We may assume that a child or an adolescent can at least understand and anticipate the higher stages such as the Conjunctive Faith style and may also be able to adopt them on a trial basis. I thus refute the belief that more advanced styles of faith cannot be expected to or taught to children-a belief that is based on the false assumption that particular stages do not emerge and cannot be understood before 
a certain age, making it worthless to refer to them in teaching. Here, my two key proposals for the future of faith development theory may converge: New engagement in empirical scrutiny may reveal a greater flexibility and complexity of faith development and thus confirm the enlargement of our vision of developmental growth. Especially in regard to fundamentalist faith orientations, which I would like to add explicitly to Fowler's list of challenges of the new millennium, the faith development perspective has much to offer ${ }^{6}$ and should influence our teaching in religious education.

Heinz Streib, Ph.D./Emory Univ. is professor for religious education and ecumenical theology, and directs the Research Center for Biographical Studies in Contemporary Religion at the University of Bielefeld, Germany. E-mail: Heinz.Streib@uni-bielefeld.de

\section{REFERENCES}

Fowler, J. W. 1996. Faithful change. The personal and public challenges of postmodern life. Nashville, Tenn.: Abingdon Press.

Fowler, J. W., Streib, H., and Keller, B. 2004. Manual for faith development research. (3rd ed.) Bielefeld; Atlanta: Research Center for Biographical Studies in Contemporary Religion, University of Bielefeld; Center for Research in Faith and Moral Development, Emory University. Available online at http://wwwhomes.uni-bielefeld.de/religions for schung/

Gmünder, P. 1979. Entwicklung als Ziel der religiösen Erziehung. Bericht über ein Forschungsprojekt "Entwicklung kognitiver Stufen des religiösen Urteils." Katechetische Blätter, 104:629-634.

Kohlberg, L., and R. Mayer. 1972. Development as the aim of education: The Dewey View. In Essays on Moral Development, Vol.I. The Philosophy of Moral Development, ed., L. Kohlberg. San Francisco: Harper \& Row, 49-96.

Moseley, R. M., Jarvis, D., and J. W. Fowler. 1986. Manual for faith development research. Atlanta: Center for Faith Development, Emory University.

Moseley, R. M., Jarvis, D., and J. W. Fowler. 1993. Manual for faith development research, 2nd ed. Atlanta: Center for Research in Faith and Moral Development, Emory University.

Streib, H. 1999. Off-road religion? A narrative approach to fundamentalist and occult orientations of adolescents. Journal of Adolescence 22:255-267.

Streib, H. 2001a. Faith development theory revisited: The religious styles perspective. International Journal for the Psychology of Religion, 11:143-158.

Streib, H. 2001b. Fundamentalism as challenge to religious education. Religious Education 96: 227-244.

Streib, H. 2003a. Faith development research at twenty years. In Developing a public faith. New directions in practical theology. Essays in honor of James. W. Fowler, eds. R. R. Osmer and F. Schweitzer. St. Louis: Chalice Press, 15-42.

Streib, H. 2003b. Religion as a question of style: Revising the structural differentiation of religion from the perspective of the analysis of the contemporary pluralistic-religious situation. International Journal for Practical Theology 7:1-22.

Streib, H. 2003c. Variety and complexity of religious development: Perspectives for the 21st century. In One hundred years of psychology of religion. Issues and trends in a century

${ }^{6}$ See also my analysis and proposal for explaining fundamentalism and responding to it in religious education (Streib 1999, 2001a, 2001b). 
long quest, eds. P. H. M. P. Roelofsma, J. M. T. Corveleyn, and J. W. Van Saane, Amsterdam: Free University Press, 123-138.

Streib, H. 2004. Faith development research revisited: Accounting for diversity in structure, content, and narrativity of faith. International Journal for the Psychology of Religion, 14(4).

Vanlue, N. S. 1996. A meta-analysis of the concepts, characteristics, and variables addressed in sixty doctoral dissertations highly relevant to adult faith development (1980-1994). Ed.D. Diss., Ball State University.

Walter, W. J., Jr. 1996. Books in religious adult education valued by professional religious adult educators. Ed.D. Diss., University of North Texas. 